\title{
FUNCTIONAL PROFILE OF ACTIVE OLDER ADULTS WITH LOW BACK PAIN, ACCORDING TO THE ICF
}

PERFIL FUNCIONAL DE IDOSOS ATIVOS COM DOR LOMBAR DE ACORDO COM A CIF

PERFIL FUNCIONAL DE LOS ANCIANOS ACTIVOS CON DOLOR LUMBAR SEGÚN LA CIF

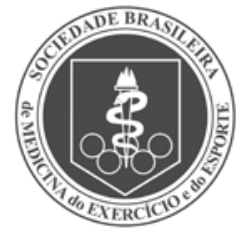

Original Article

Artigo Original Artículo Original
Andersom Ricardo Fréz' (Physiotherapist)

Aline Cristiane Binda'

(Physiotherapist)

Angela Dubiela' (Physiotherapist)

Christiane Riedi Daniel ${ }^{1}$

(Physiotherapist)

Gladson Ricardo Flor Bertolini²

(Physiotherapist)

João Afonso Ruaro' (Physiotherapist)

Juliana Souza de Oliveira ${ }^{3}$

(Physiotherapist)

Marina Pegoraro Baroni'

(Physiotherapist)

1. Universidade Estadual do CentroOeste (UNICENTRO), Department of Physical Therapy, Guarapuava, PR, Brazil.

2. Universidade Estadual do Oeste do Paraná (UNIOESTE), Department of Physical Therapy, Cascavel, PR, Brazil. 3. University of Sydney, Sydney Medical School, George Institute for Global Health, Sydney, Australia.

\section{Correspondence:}

Rua Simeão Camargo Varela de Sá, Guarapuava, PR, Brazil. 85040-080. frez@unicentro.br

\begin{abstract}
Introduction: The International Classification of Functioning, Disability and Health (ICF) considers multiples aspects of functionality. It is believed that this tool can help to classify the functionality of older adults with low back pain (LBP). Objectives: To describe the functionality of active older adults with LBP according to the ICF. Methods: A transversal study was conducted using the brief ICF core set for low back pain, to establish functional profiles of 40 older adults. The ICF categories were considered valid when $\geq 20 \%$ of participants showed some disability. Results: Thirty-two of the 35 categories of the brief ICF core set could be considered representative of the sample. Conclusion: The brief ICF core set for LBP results demonstrated that this classification system is representative for describing the functional profile of the sample.
\end{abstract}

Keywords: aged; low back pain; health evaluation; international classification of functioning, disability and health.

\section{RESUMO}

Introdução: A Classificação Internacional de Funcionalidade, Incapacidade e Saúde (CIF) considera múltiplos aspectos da funcionalidade. Acredita-se que essa ferramenta pode auxiliar a classificar a funcionalidade de idosos com dor lombar (DL). Objetivos: Descrever a funcionalidade de idosos ativos com DL de acordo com a CIF. Métodos: Foi realizado um estudo transversal para estabelecer o perfil funcional de 40 idosos, utilizando a versão abreviada do core set da CIF para dor lombar. As categorias da CIF foram consideradas válidas quando $\geq 20 \%$ dos participantes apresentavam alguma deficiência. Resultado: Trinta e duas das 35 categorias da versão abreviada do core set da CIF para DL foram consideradas representativas da amostra. Conclusão: Os resultados da versão abreviada do core set da CIF para DL demonstraram que esse é um sistema de classificação representativo para descrever o perfil funcional da amostra.

Descritores: idoso; dor lombar; avaliação em saúde; classificação internacional de funcionalidade, incapacidade e saúde.

\section{RESUMEN}

Introducción: La Clasificación Internacional del Funcionamiento, de la Discapacidad y de la Salud (CIF) considera varios aspectos de la funcionalidad. Se cree que esta herramienta puede ayudar a clasificar la funcionalidad de los ancianos con dolor lumbar (DL). Objetivos: Describir la funcionalidad de los ancianos activos con DL según la CIF. Métodos: Un estudio transversal se llevó a cabo para establecer el perfil funcional de 40 ancianos utilizando la versión abreviada del core set de la CIF para el dolor lumbar. Las categorías de la CIF se consideraron válidas cuando $\geq 20 \%$ de los participantes tenían una discapacidad. Resultado: Treinta y dos de las 35 categorías de la versión abreviada del core set de la CIF se consideraron representativas de la muestra. Conclusión: Los resultados de la versión abreviada del core set de la CIF para DL muestra que se trata de un sistema de clasificación representativo para describir el perfil funcional de la muestra.

Descriptores: anciano; dolor de la región lumbar; evaluación en salud; clasificación internacional del funcionamiento, de la discapacidad y de la salud.

\section{INTRODUCTION}

Low back pain (LBP) is a common health problem across all age groups $\mathrm{s}^{1-3}$. Generally females and older people report more LBP 4,5 , whereas older adults have a higher risk of frequency LBP compared with young adults ${ }^{6}$.

In order to develop efficient health care strategies targeted at the needs of the older people, information about the patterns of functional health conditions is required. Functioning is considered as an important outcome in LBP7 ${ }^{7}$. Thus, concepts, classifications, and measurements of functioning and health in patients with LBP are of crucial importance in clinical practice and research. In this context, the International Classification of Functioning, Disability and Health (ICF), developed by the World Health Organization, is a reference framework and classification system for measuring human functioning. The ICF is a toll that provides a comprehensive description of the wide spectrum of human functioning ${ }^{8}$. 
The acceptance and application of ICF as universal framework and classification has been facilitated by its development and consensus process in the world, with growing evidence of its validity ${ }^{9}$. In order to enhance the feasibility of its use, the core sets project began to be developed. The core set project aims to extract a tailored selections of ICF categories from the entire classification to represent the standards of specific groups for multidisciplinary approach ${ }^{10}$.

The ICF core set for LBP was developed to guide multidisciplinary assessments and to be used for patients with non-specific LBP. The brief ICF core set includes 10 categories of component body functions, three categories of component body structures, 12 categories of component activities and participation and 10 categories of component environmental factors ${ }^{11}$.

The ICF core sets for LBP can be used to describe the experience of such patients ${ }^{12}$, however, for older adults the ICF use is incipient. The purpose of this study was to describe functioning in a sample of older adults with chronic non-specific LBP.

\section{METHODS}

The current study was a cross-sectional, research among active older community-dwelling in Guarapuava/Paraná/Brazil. The older people were enrolled by a convenience sample from two groups of supervised aquatic and land-based exercises.

Eligibility criteria were LBP, age 60 to 75 years old, physically active. Patients with lumbar fracture or surgery, or rheumatic or neurological disease were excluded.

The study was approved by the Ethics Committee of the Universidade Estadual do Centro-Oeste (ruling number 101.689/2012). It adhered to Brazilian laws and guidelines concerning human research. The participants who were eligible were informed about the study procedures and those who agreed to participate in the study signed consent form.

The brief ICF core set for LBP was used to establish the sample's functional profile ${ }^{11}$. The evaluation was conducted by a health professional, trained and experienced in ICF's use.

To consider the representativeness of the ICF categories, we used the Jonsdottir et al. ${ }^{13}$ recommendation, in which at least $20 \%$ of the elderly sample had some disability in it. The result of the sum of older adults with qualifiers 1, 2, 3 and 4 should be equal to or greater than $20 \%$ of the sample for each category ${ }^{12,14}$.

The qualifiers 1, 2, 3 and 4, which represent progressive levels of disability, were grouped under the column "some disability". Qualifiers 0 and 9, which indicate "no problem" and "not applicable", respectively, were grouped under the column "no problem". The qualifier 8, "not specified" was used when the evaluation was not possible 8 .

The body function, body structures and activities and participation categories were shown as percentages of "no problem" versus "some disability". For environmental factors categories were shown as percentages of "facilitator" and "neither a facilitator nor a barrier".

\section{RESULTS}

A total of 102 people were screened for this study. Sixty-two were excluded for do not have LBP. The remaining 40 participants were all evaluated ( 5 male and 35 female, mean age 67.2 \pm 6.0 years old). The demographic characteristics of the participants are presented in Table 1.

Table 2 shows the frequency of body functions categories, which can be observed that only the category b735 (muscle tone functions) was not valid, because it showed more than $87 \%$ of the sample without problem.

Already the categories of body structures and activities and participation, all of them were considered valid (Tables 3 and 4).
As for the environmental factors component, only the categories e110 (products or substances for personal consumption) and e135 (products and technology for employment) was not valid, because all elderly did not need these facilitators (Table 5).

Regarding facilitator or barrier for environmental factors, in none category was observed higher levels of disability. Therefore, there were not more than $50 \%$ of older adults rated by 3 or 4 qualifiers. When observed facilitators, only health services, systems and policies (category e580) were considered by all subjects as a facilitator.

Of the 35 categories of the brief ICF core set for LBP, 32 categories (91.4\%) were considered as representative of the sample.

Table 1. Characteristics of the participants $(n=40)$.

\begin{tabular}{|c|c|}
\hline Gender & $\mathrm{n}(\%)$ \\
\hline Male & $5(12.5)$ \\
\hline Female & $35(87.5)$ \\
\hline Age, mean (SD) & $67.2(6.0)$ \\
\hline Smoker, n (\%) & $2(5.0)$ \\
\hline Body mass index $\left(\mathrm{kg} / \mathrm{m}^{2}\right)$ & $\mathrm{n}(\%)$ \\
\hline Health weight (18.5-24.9) & $13(32.5)$ \\
\hline Overweight (25.0-29.9) & $23(57.5)$ \\
\hline Obese $(\geq 30)$ & $4(10.0)$ \\
\hline Daily painkillers use, n (\%) & $24(60.0)$ \\
\hline Education & $\mathrm{n}(\%)$ \\
\hline Illiterate & $17(42.5)$ \\
\hline Elementary & $7(17.5)$ \\
\hline High school & $10(25.0)$ \\
\hline College & $6(15.0)$ \\
\hline Income & $\mathrm{n}(\%)$ \\
\hline 1-3 BR MW & $35(87.5)$ \\
\hline 4-6 BR MW & $3(7.5)$ \\
\hline 7-10 BR MW & $1(2.5)$ \\
\hline$>10 \mathrm{BR} M W$ & $1(2.5)$ \\
\hline
\end{tabular}

SD: standard deviation; BR MW: Brazilian minimum wage.

Table 2. Frequency distribution of older adults with body function disability $(n=40)$.

\begin{tabular}{c|c|c|c|c|c|c|c|c|c|c}
\hline \multirow{2}{*}{ ICF Categories } & \multicolumn{7}{c}{ ICF Qualifiers } \\
\cline { 2 - 12 } & \multicolumn{6}{|c|}{ Some disability } & \multicolumn{2}{c|}{$\begin{array}{c}\text { No } \\
\text { problem }\end{array}$} & \multicolumn{2}{c}{$\begin{array}{c}\text { Not } \\
\text { specified }\end{array}$} \\
\cline { 2 - 13 } & $\mathbf{1}$ & $\mathbf{2}$ & $\mathbf{3}$ & $\mathbf{4}$ & $\%$ & $\mathbf{0}$ & $\mathbf{9}$ & $\%$ & $\mathbf{8}$ & $\%$ \\
\hline b130 Energy and drive functions & 16 & 3 & 3 & 1 & 57.5 & 17 & - & 42.5 & - & - \\
\hline b134 Sleep functions & 23 & 9 & 2 & 1 & 87.5 & 4 & - & 10.0 & 1 & 2.5 \\
\hline b152 Emotional functions & 19 & 15 & 1 & 2 & 92.5 & 3 & - & 7.5 & - & - \\
\hline b280 Sensation of pain & 7 & 17 & 4 & 9 & 92.5 & 3 & - & 7.5 & - & - \\
\hline b455 Exercise tolerance functions & 14 & 15 & 2 & 2 & 82.5 & 6 & - & 15.0 & 1 & 2,5 \\
\hline b710 Mobility of joint functions & 11 & 17 & 3 & 6 & 92.5 & 3 & - & 7.5 & - & - \\
\hline b715 Stability of joint functions & 10 & 14 & 3 & 1 & 70.0 & 11 & - & 27.5 & 1 & - \\
\hline b730 Muscle power functions & 13 & 18 & 3 & 2 & 90.0 & 4 & - & 10.0 & - & - \\
\hline b735 Muscle tone functions & 5 & - & - & - & 12.5 & 35 & - & 87.5 & - & - \\
\hline b740 Muscle endurance functions & 7 & 8 & 9 & 8 & 80.0 & 8 & - & 20.0 & - & - \\
\hline
\end{tabular}

Table 3. Frequency distribution of older adults with body structure disability $(n=40)$.

\begin{tabular}{c|c|c|c|c|c|c|c|c|c|c}
\hline \multirow{2}{*}{ ICF Categories } & \multicolumn{7}{c|}{ ICF Qualifiers } \\
\cline { 2 - 12 } & \multicolumn{3}{|c|}{ Some disability } & \multicolumn{3}{c|}{$\begin{array}{c}\text { No } \\
\text { problem }\end{array}$} & \multicolumn{2}{c}{$\begin{array}{c}\text { Not } \\
\text { specified }\end{array}$} \\
\cline { 2 - 11 } & $\mathbf{1}$ & $\mathbf{2}$ & $\mathbf{3}$ & $\mathbf{4}$ & $\%$ & $\mathbf{0}$ & $\mathbf{9}$ & $\mathbf{8}$ & $\mathbf{8}$ & $\%$ \\
\hline $\begin{array}{c}\text { s120 Spinal cord and } \\
\text { related structures }\end{array}$ & 9 & 14 & 3 & 3 & 72.5 & $\mathbf{9}$ & - & 22.5 & 2 & 5.0 \\
\hline s760 Structure of trunk & 3 & 13 & 8 & 4 & 70.0 & 7 & - & 17.5 & 5 & 12.5 \\
\hline $\begin{array}{c}\text { s770 Additional musculoskeletal } \\
\text { structures related to movement }\end{array}$ & 8 & 12 & 3 & 1 & 60.0 & 15 & - & 37.5 & 1 & 2.5 \\
\hline
\end{tabular}


Table 4. Frequency distribution of older adults with activities and participation disability $(n=40)$.

\begin{tabular}{|c|c|c|c|c|c|c|c|c|c|c|}
\hline \multirow{3}{*}{ ICF Categories } & \multicolumn{10}{|c|}{ ICF Qualifiers } \\
\hline & \multicolumn{5}{|c|}{ Some disability } & \multicolumn{3}{|c|}{$\begin{array}{c}\text { No } \\
\text { problem }\end{array}$} & \multicolumn{2}{|c|}{$\begin{array}{c}\text { Not } \\
\text { specified }\end{array}$} \\
\hline & 1 & 2 & 3 & 4 & $\%$ & 0 & 9 & $\%$ & 8 & $\%$ \\
\hline $\begin{array}{l}\mathrm{d} 240 \text { Handling stress and other } \\
\text { psychological demands }\end{array}$ & 14 & 14 & 4 & 2 & 85.0 & 6 & - & 15.0 & - & - \\
\hline $\begin{array}{l}\mathrm{d} 410 \text { Changing basic body } \\
\text { position }\end{array}$ & 8 & 8 & 7 & 3 & 65.0 & 14 & - & 35.0 & - & - \\
\hline d415 Maintaining a body position & 12 & 7 & 5 & 1 & 62.5 & 13 & - & 32.5 & 2 & 5.0 \\
\hline d430 Lifting and carrying objects & 10 & 8 & 4 & 7 & 72.5 & 11 & - & 27.5 & - & - \\
\hline d450 Walking & 4 & 3 & 4 & 6 & 42.5 & 23 & - & 57.5 & - & - \\
\hline d530 Toileting & 5 & 7 & 2 & - & 35.0 & 26 & - & 65.0 & - & - \\
\hline d540 Dressing & 5 & 7 & 2 & - & 35.0 & 26 & - & 65.0 & - & - \\
\hline d640 Doing housework & 4 & 4 & 2 & 2 & 30.0 & 28 & - & 70.0 & - & - \\
\hline d760 Family relationships & 6 & 2 & - & - & 20.0 & 32 & - & 80.0 & - & - \\
\hline $\begin{array}{l}\text { d845 Acquiring, keeping and } \\
\text { terminating a job }\end{array}$ & 2 & 2 & 3 & 5 & 30.0 & 22 & - & 55.0 & 6 & 15.0 \\
\hline d850 Remunerative employment & 2 & 2 & 3 & 5 & 30.0 & 22 & - & 55.0 & 6 & 15.0 \\
\hline $\begin{array}{l}\text { d859 Work and employment, } \\
\text { other specified and unspecified }\end{array}$ & 2 & 2 & 3 & 5 & 30.0 & 22 & - & 55.0 & 6 & 15.0 \\
\hline
\end{tabular}

Table 5. Frequency distribution of older adults with facilitator or barrier for environmental factors $(n=40)$.

\begin{tabular}{|c|c|c|c|c|c|c|c|c|c|c|}
\hline \multirow{3}{*}{ ICF Categories } & \multicolumn{10}{|c|}{ ICF Qualifiers } \\
\hline & \multicolumn{5}{|c|}{ Facilitator } & \multicolumn{3}{|c|}{$\begin{array}{c}\text { Neither a } \\
\text { facilitator nor } \\
\text { a barrier }\end{array}$} & \multicolumn{2}{|c|}{$\begin{array}{c}\text { Not } \\
\text { specified }\end{array}$} \\
\hline & 1 & 2 & 3 & 4 & $\%$ & 0 & 9 & $\%$ & 8 & $\%$ \\
\hline $\begin{array}{l}\text { e110 Products or substances } \\
\text { for personal consumption }\end{array}$ & - & - & - & - & - & 16 & - & 40.0 & 24 & 60.0 \\
\hline $\begin{array}{l}\text { e135 Products and technology } \\
\text { for employment }\end{array}$ & - & - & - & - & - & - & 40 & 100.0 & - & - \\
\hline $\begin{array}{l}\text { e155 Design, construction } \\
\text { and building products and } \\
\text { technology of buildings } \\
\text { for private use }\end{array}$ & 22 & 6 & - & 0 & 70.0 & 12 & - & 30.0 & - & - \\
\hline e310 Immediate family & 2 & 5 & 2 & 1 & 25.0 & 30 & - & 75.0 & - & - \\
\hline e355 Health professionals & 9 & 5 & 4 & 1 & 47.5 & 21 & - & 52.5 & - & - \\
\hline $\begin{array}{l}\text { e } 410 \text { Individual attitudes of } \\
\text { immediate family members }\end{array}$ & 5 & 1 & 1 & 2 & 22.5 & 30 & - & 75.0 & 1 & 2.5 \\
\hline $\begin{array}{l}\text { e450 Individual attitudes of } \\
\text { health professionals }\end{array}$ & 4 & 12 & 4 & 7 & 67.5 & 12 & - & 30.0 & 1 & 2.5 \\
\hline $\begin{array}{c}\text { e550 Legal services, systems } \\
\text { and policies }\end{array}$ & 20 & 10 & 1 & - & 77.5 & 4 & - & 10.0 & 5 & 12.5 \\
\hline $\begin{array}{l}\text { e570 Social security services, } \\
\text { systems and policies }\end{array}$ & 11 & 13 & 2 & 3 & 72.5 & 4 & - & 10.0 & 7 & 17.5 \\
\hline $\begin{array}{l}\text { e580 Health services, systems } \\
\text { and policies }\end{array}$ & 16 & 16 & 2 & 6 & 100.0 & - & - & - & - & - \\
\hline
\end{tabular}

\section{DISCUSSION}

Currently, it has been demonstrated the importance of a physically active lifestyle for older people ${ }^{15}$. Breaking-up sedentary time is associated with better physical function in older adults; and, it may have an important place in future guidelines on preserving older adults' physical function to support activities of daily living ${ }^{16}$. The sedentary lifestyle accelerates the effects of aging in susceptible individuals inducing mechanisms which lead to risk factors of chronic diseases $^{17}$, as well as LBP.

Despite of the ICF use be incipient, there is a growing interest in its using ${ }^{18,19}$. Such use is in the process of consolidation the understanding of full human functioning, showing possible relationships and interactions between conditions and theirs determinants, which may results in disability ${ }^{20}$. Moreover, the growth potential of the ICF is compatible with the demand of knowledge generated by the same in public and private sectors by involving the relationships between health, environment and functionality, especially in health indicators ${ }^{19}$, fully factors related to aging.

The brief ICF core set for LBP was used to establish the functional profile, contributing to the research about multidimensional assessment aspects of the older people functionality.

To consider the representativeness of the ICF categories, the frequency of $20 \%$ of individuals with some disability was chosen which was a similar percentage used in others studies ${ }^{12-14}$ to validate the ICF core set for LBP.

Regarding the sample of elderly of this study, the brief core set for LBP was able to assess the functioning including body functions and structures, activities and participation and environmental factors, because $91.4 \%$ of the categories were considered representative of the sample.

Only three categories were not considered valid because they showed no impairment in $>80 \%$ of the sample: b735 (muscle tone functions), e110 (products or substances for personal consumption) and e135 (products and technology for employment).

The b735 is describe as functions related to the tension present in the resting muscles and the resistance offered when trying to move the muscles passively, and includes impairments such as hypotonia, hypertonia and muscle spasticity ${ }^{8}$. These symptoms are related to the neurological dysfunction of the spine, which can lead LBP. However, in the sample of the present study only five older adults showed some disability related to muscle tone functions, and they were indicate as low impairment.

Furthermore, two categories of component environmental factors were also considered not valid. Firstly, e110 is described as products or substances for personal consumption any natural or human-made object or substance gathered, processed or manufactured for ingestion, which includes food and drugs ${ }^{8}$. Forty percent of the sample related no using drugs (applied the qualifier 0 ) and the others $60 \%$ related using some drugs, however a relationship between number and/or types of drugs with the qualifiers had not been established. That category was only considered if they used painkillers or not, so the qualifier 8 was applied. Secondly, e135 is described as equipment, products and technologies used by people in daily activities, including those adapted or specially designed, located in, on or near the person using them, which includes general and assistive products and technology for personal use ${ }^{8}$. For all elderly was applied the qualifier 9 (neither a facilitator nor a barrier), because during the anamnesis no patient reported use assistive products.

Only the category e580 (health services, systems and policies) was considered by all older adults as a facilitator. The sample of older adults emphasized the importance of access to public and private health services.

In the present study no category showed a high level of disability, differently it was seen on another study ${ }^{21}$, which considered a high level of disability in wheelchair basketball athletes with spinal cord injury, with more than $50 \%$ of participants rated by qualifiers 3 or 4. This low level of disability in present study can be interpreted as supervised aquatic and land-based exercises decreases the disabilities, or these limitations do not affect the practice of regular physical 
activity. To establish this conclusion or propose another one would be require further evaluation.

Similar to another study ${ }^{21}$, the ICF considers not only the dysfunctions and disabilities of the person, but also the impact of these factors on social activities, as well as the influence of the environment, either as a facilitator or barrier to functional independence.

This study was limited to a sample of older adults with LBP belonging to a group of supervised aquatic and land-based exercises. In addition, a convenience sample does not include all older adults with LBP, which does not allow generalization of the results. On the other hand, the results show clearly that the ICF's use could be implemented in similar researches.

\section{CONCLUSION}

The brief ICF core set for LBP results demonstrated that this classification system is representative to describe the functional profile of the sample. Older adults with LBP presented impairments related to body functions and structures, activities and participation and environmental factors, however, these do not support a sedentary lifestyle because these limitations do not affect the practice of regular physical activity.

All authors have declared there is not any potential conflict of interests concerning this article.

AUTORES' CONTRIBUTIONS: Each author contributed individually and significantly to the development of the manuscript. ACB (0000-0002-6870-777X)*, AD (0000$0001-7375-6771)^{*}$ and MPB (0000-0003-0597-0690)* were the main contributors in data collection and writing of the manuscript. CRD (0000-0002-2282-1358)* and GRFB (0000-0003-0565-2019)* conducted the statistical analysis and interpretation of results. ARF (0000-0001-6085-1382)*, JAR (0000-0001-8323-3704)* and JSO (00000002-5544-1036)* carried out the literature search and review of the manuscript. All authors contributed to the intellectual concept of the study. ${ }^{*}$ Number ORCID (Open Researcher and Contributor ID).

\section{REFERENCES}

1. Shiri R, Solovieva S, Husgafvel-Pursiainen K, Taimela S, Saarikoski LA, Huupponen R, et al. The association between obesity and the prevalence of low back pain in young adults: the Cardiovascular Risk in Young Finns Study. Am J Epidemiol. 2008;167(9):1110-9.

2. Feng $C K$, Chen ML, Mao IF. Prevalence of and risk factors for different measures of low back pain among female nursing aides in Taiwanese nursing homes. BMC Musculoskelet Disord. 2007;8:52.

3. Nagasu M, Sakai K, Ito A, Tomita S, Temmyo Y, Ueno M, et al. Prevalence and risk factors for low back pain among professional cooks working in school lunch services. BMC Public Health. 2007;7:171

4. Koster A, Bosma H, Kempen Gl, van Lenthe FJ, van Eijk JT, Mackenbach JP. Socioeconomic inequalities in mobility decline in chronic disease groups (asthma/COPD, heart disease, diabetes mellitus, low back pain): only a minor role for disease severity and comorbidity. J Epidemiol Community Health. 2004;58(10):862-9.

5. Abegunde KA, Owoaje ET. Health problems and associated risk factors in selected urban and rural elderly population groups of South-West Nigeria. Ann Afr Med. 2013;12(2):90-7.

6. Chou YC, Shih CC, Lin JG, Chen TL, Liao CC. Low back pain associated with sociodemographic factors, lifestyle and osteoporosis: a population-based study. J Rehabil Med. 2013;45(1):76-80.

7. Deyo RA, Battie M, Beurskens AJ, Bombardier C, Croft P, Koes B, et al. G. Outcome measures for low back pain research. A proposal for standardized use. Spine (Phila Pa 1976). 1998;23(18):2003-13.

8. World Health Organization (WHO). International Classification of Functioning, Disability and Health: ICF. Geneva: WHO; 2001

9. Cieza A, Stucki G. The International Classification of Functioning Disability and Health: its development process and content validity. Eur J Phys Rehabil Med. 2008;44(3):303-13.

10. Røe C, Sveen U, Geyh S, Cieza A, Bautz-Holter E. Construct dimensionality and properties of the categories in the ICF Core Set for low back pain. J Rehabil Med. 2009;41(6):429-37.
11. Cieza A, Stucki G, Weigl M, Disler P, Jäckel W, van der Linden S, et al. ICF Core Sets for low back pain. J Rehabil Med. 2004;(44 Suppl):69-74.

12. Riberto M, Chiappetta LM, Lopes KA, Chiappetta LR. A transversal multicenter study assessing functioning, disability and environmental factors with the comprehensive ICF core set for low back pain in Brazil. Eur J Phys Rehabil Med. 2014;50(2):153-60.

13. Jonsdottir J, Rainero G, Racca V, Glässel A, Cieza A. Functioning and disability in persons with low back pain. Disabil Rehabil. 2010;32 Suppl 1:578-84.

14. Riberto M, Chiappetta LM, Lopes KAT, Battistella LR. The Brazilian experience with the international classification of functioning, disability and health core set for low back pain. Coluna/Columna. 2011;10(2):121-6

15. Withall J, Stathi A, Davis M, Coulson J, Thompson JL, Fox KR. Objective indicators of physical activity and sedentary time and associations with subjective well-being in adults aged 70 and over. Int J Environ Res Public Health. 2014 Jan 2;11(1):643-56

16. Sardinha LB, Santos DA, Silva AM, Baptista F, Owen N. Breaking-up sedentary time is associated with physical function in older adults. J Gerontol A Biol Sci Med Sci. 2015;70(1):119-24.

17. Charansonney OL. Physical activity and aging: a life-long story. Discov Med. 2011;12(64):177-85.

18. Comín Comín M, Ruiz Garrós C, Franco E, Damian J, Ruiz Tovar M, de Pedro-Cuesta J. Scientificprofessional production on the ICF disability model in Spain. A literature review (2001-2010). Gac Sanit. 2011;25(Suppl 2):39-46

19. Ruaro JA, Ruaro MB, Souza DE, Fréz AR, Guerra RO. An overview and profile of the ICF's use in Brazil--a decade of history. Rev Bras Fisioter. 2012;16(6):454-62.

20. Sampaio RF, Luz MT. Human functioning and disability: exploring the scope of the World Health Organization's international classification. Cad Saude Publica. 2009;25(3):475-83.

21. Fréz AR, Souza AT, Quartiero CRB, Ruaro JA. Functional profile of wheelchair basketball athletes with spinal cord injury according to the ICF. Rev Bras Med Esporte. 2014;20(1):78-81. 